\title{
JOURNAL of PALEONTOLOGY
}

mis (restis

Paleontological

\section{VOL 94 | NO 6 | NOVEMBER 2020}

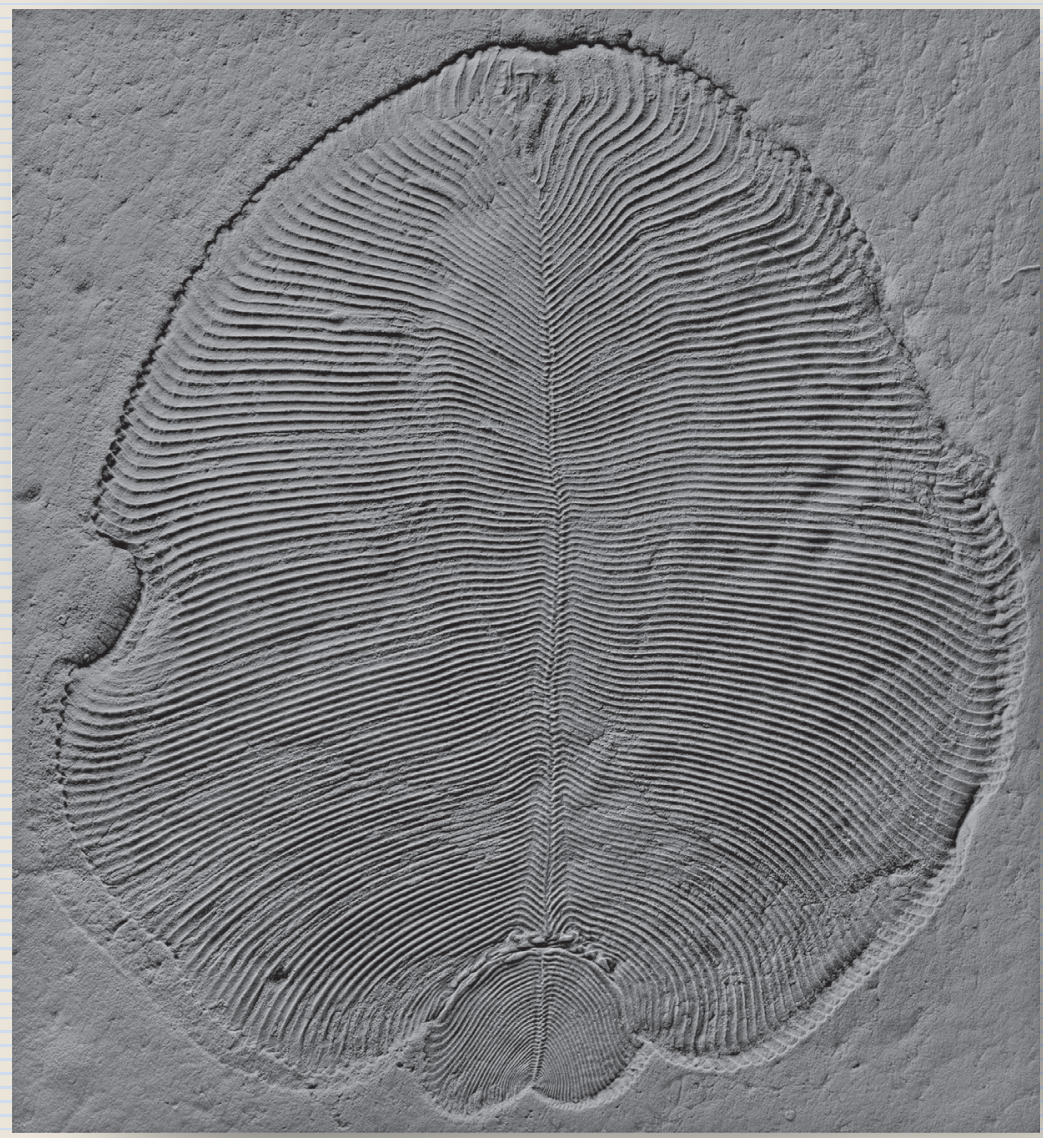

\section{CAMBRIDGE}

UNIVERSITY PRESS 


\section{OFFICERS AND EDITORS OF THE PALEONTOLOGICAL SOCIETY}

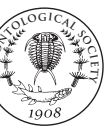

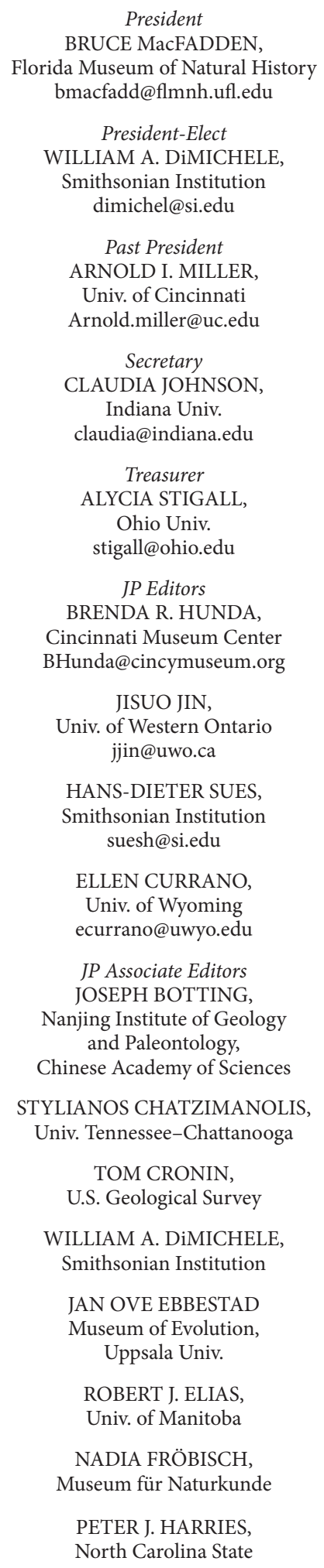

President

BRUCE MacFADDEN,

Florida Museum of Natural History

bmacfadd@flmnh.ufl.edu

President-Elect

WILLIAM A. DiMICHELE,

Smithsonian Institution

dimichel@si.edu

Past President

ARNOLD I. MILLER,

Univ. of Cincinnati

Arnold.miller@uc.edu$$
\text { Secretary }
$$

CLAUDIA JOHNSON, Indiana Univ.

claudia@indiana.edu

Treasurer

ALYCIA STIGALL,

Ohio Univ.

stigall@ohio.edu

JP Editors

BRENDA R. HUNDA,

Cincinnati Museum Center

BHunda@cincymuseum.org

JISUO JIN,

Univ. of Western Ontario jjin@uwo.ca

HANS-DIETER SUES, Smithsonian Institution suesh@si.edu

ELLEN CURRANO,

Univ. of Wyoming

ecurrano@uwyo.edu

JP Associate Editors JOSEPH BOTTING,

Nanjing Institute of Geology and Paleontology,

Chinese Academy of Sciences

STYLIANOS CHATZIMANOLIS,

Univ. Tennessee-Chattanooga

TOM CRONIN,

U.S. Geological Survey

WILLIAM A. DiMICHELE,

Smithsonian Institution

JAN OVE EBBESTAD

Museum of Evolution,

Uppsala Univ.

ROBERT J. ELIAS,

Univ. of Manitoba

NADIA FRÖBISCH,

Museum für Naturkunde

PETER J. HARRIES,

North Carolina State

MICHAEL HAUTMANN, Univ. of Zurich

MARTIN J. HEAD, Brock Univ.

THOMAS HEGNA,

Western Illinois Univ.

SAMANTHA HOPKINS,

Univ. of Oregon

NIGEL HUGHES

Univ. of California

NATHAN JUD,

Univ. of Florida

MICHAEL KAMINSKI

King Fahd University of Petroleum and Minerals

DANIEL KSEPKA, Bruce Museum

JAMES LAMSDELL, West Virginia Univ.

MAX LANGER, Universidade de São Paulo

BERTRAND LEFEBVRE, Lyon Univ.

STEPHEN A. LESLIE, James Madison Univ.

BRUCE LIEBERMAN, Univ. of Kansas

ALEX LIU, Univ. of Cambridge

STEVEN LoDUCA, Eastern Michigan Univ.

RICK LUPIA, Univ. of Oklahoma

GABRIELA MÁNGANO,

Univ. of Saskatchewan

GREG McDONALD, Bureau of Land Management

RICHARD MOOI, California Academy of Sciences

ALISON MURRAY,

Univ. of Alberta

PAULA NOBLE,

Univ. of Nevada

ANDRZEJ PISERA, Polish Academy of Sciences

BRIAN PRATT,

Univ. of Saskatchewan
SIMON SCHNEIDER, CASP

CRAIG SCOTT

Royal Tyrrell Museum of Paleontology

MARY SILCOX,

Univ. of Toronto Scarborough

EDUARDO LEORRI SORIANO,

East Carolina Univ., Greenville

COLIN SPROAT

Univ. of Saskatchewan

DAVID VARRICCHIO,

Montana State Univ.

STEVE WESTROP,

Oklahoma Museum

DAVID M. WORK,

Maine State Museum

MARGARET M. YACOBUCCI,

Bowling Green State Univ.

SAMUEL ZAMORA,

Geological Survey of Spain

RENBIN ZHAN,

Nanjing Institute of Geology and Palaeontology,

Chinese Academy of Sciences

SHUNXIN ZHANG,

Canada-Nunavut Geoscience Office

ZHIFEI ZHANG,

Northwest Univ.

Paleobiology Senior Editor

MARK PATZKOWSKY, Penn State Univ.

Paleobiology Co-Editors

NADIA FRÖBISCH,

Museum für Naturkunde

KEVIN BOYCE,

Stanford Univ.

WOLFGANG KIESSLING,

Universitat Erlangen

JAMES CRAMPTON, GNA Science

Managing Editor

JESSICA KASTIGAR,

JournalofPaleontology@cambridge.org

Paleobiology@cambridge.org

Communications Officer

TAORMINA LEPORE,

Univ. of California, Berkeley

tlepore@berkeley.edu

Program Coordinator

MATTHEW CLAPHAM,

Univ. of California, Santa Cruz mclapham@ucsc.edu
Editor, Special Publications COLIN SUMRALL,

Univ. of Tennessee, Knoxville csumrall@utk.edu

Education/Outreach Coordinator

ROWAN LOCKWOOD,

College of William \& Mary rxlock@wm.edu

Diversity and Inclusion Coordinator DENA SMITH,

Univ. of Colorado

dena.smith@colorado.edu

Amateur/Avocational Liaison

LINDA MCCALL,

lndmccall02@yahoo.com

Representatives At Large

GABRIELA MÁNGANO,

Univ. of Saskatchewan

gabriela.mangano@usask.ca

PHOEBE COHEN, Williams College

pac3@williams.edu

Student Representative BRIDGET KELLY,

Univ. of California, Riverside bkell006@ucr.edu

ANNAKA CLEMENT,

North Dakota State Univ.

annaka.clement@ndsu.edu

Section Chairs

Cordilleran:

CARLIE PIETSCH,

San Jose State Univ.

carlie.pietsch@sjsu.edu

North Central:

CARRIE SCHWEITZER,

Kent State Univ.

cschweit@kent.edu

Northeastern:

JACALYN WITTMER

MALINOWSKI,

SUNY Geneseo

malinowski@geneseo.edu

Rocky Mountain: BROOKE LONG-FOX,

S. Dakota School of Mines \& Tech. brooke.long@mines.sdsmt.edu

South Central:

VICTORIA CHRAIBI,

Tarleton State Univ.

chraibi@tarleton.edu

Southeastern:

TOM TOBIN,

Univ. of Alabama

ttobin@ua.edu

Cover illustration: Plan view of Dickinsonia cf. D. menneri from the Ust-Pinega Formation, Late Vendian, Southeastern White Sea area. Ivantsov

et al., Fig. 4.1.

ISSN 0022-3360

Copyright $\odot 2020$ The Paleontological Society. All rights reserved. 


\section{SUBSCRIPTION INFORMATION}

The Journal of Paleontology [ISSN 0022-3360] is published bimonthly (January, March, May, July, September, and November) by Cambridge University Press (One Liberty Plaza, 20th Floor, New York, NY 10006) for the Paleontological Society. Members of the Paleontological Society automatically receive electronic subscriptions to the Journal of Paleontology and Paleobiology as a benefit of membership. Institutional subscriptions can be purchased direct from Cambridge University Press or through any major subscription agent. Print-only, online-only, and bundled print and online prices are all available, and subscription prices are tiered according to institution type and size.

Please contact Cambridge University Press for further details:

For customers in North America

Email: subscriptions_newyork@ cambridge.org; Phone: (800) 872-7423, option 4

For customers outside of North America

Email: journals@cambridge.org;

Phone: +44 (0)1223-32-6070; Fax: +44 (0)1223-32-5150

Downloads of individual articles are available on https://www.cambridge.org/core/journals/journal-of-paleontology.

Reprints of individual articles may be ordered. For information on reprints, please contact Cambridge University Press.

Archives of previous issues are available on https://www.cambridge.org/core/journals/journal-of-paleontology.

Permissions All rights reserved. Permissions and reproduction policies, request forms, and contacts are available at: http://www.cambridge.org/ about-us/rights-permissions/

\section{ADVERTISING}

To advertise in the journal please contact M. J. Mrvica Associates, 2 West Taunton Avenue, Berlin, NJ 08009; Phone: 856-768-9360; Fax: 856753-0064; Email: mjmrvica@mrvica.com

\section{ABSTRACTING AND INDEXING}

Abstracting and indexing information for the Journal of Paleontology is available at: https://www.cambridge.org/core/journals/journal-of-paleontology/information/abstracting-and-indexing.

\section{POSTAL INFORMATION}

Periodicals postage rate paid at New York, NY, and at additional mailing offices. POSTMASTER: Send address changes in the USA, Canada, and Mexico to: Journal of Paleontology, Cambridge University Press, Journals Fulfillment Department, One Liberty Plaza, 20th Floor, New York, NY 10006. Send address changes elsewhere to the Journal of Paleontology, Cambridge University Press, Journals Fulfillment Department, UPH, Shaftesbury Road, Cambridge CB2 8BS, England.

Copyright () 2020 The Paleontological Society. All rights reserved.

Printed in the United States of America 


\section{Dinosaur Facts and Figures}

\section{The Theropods}

and Other Dinosauriformes

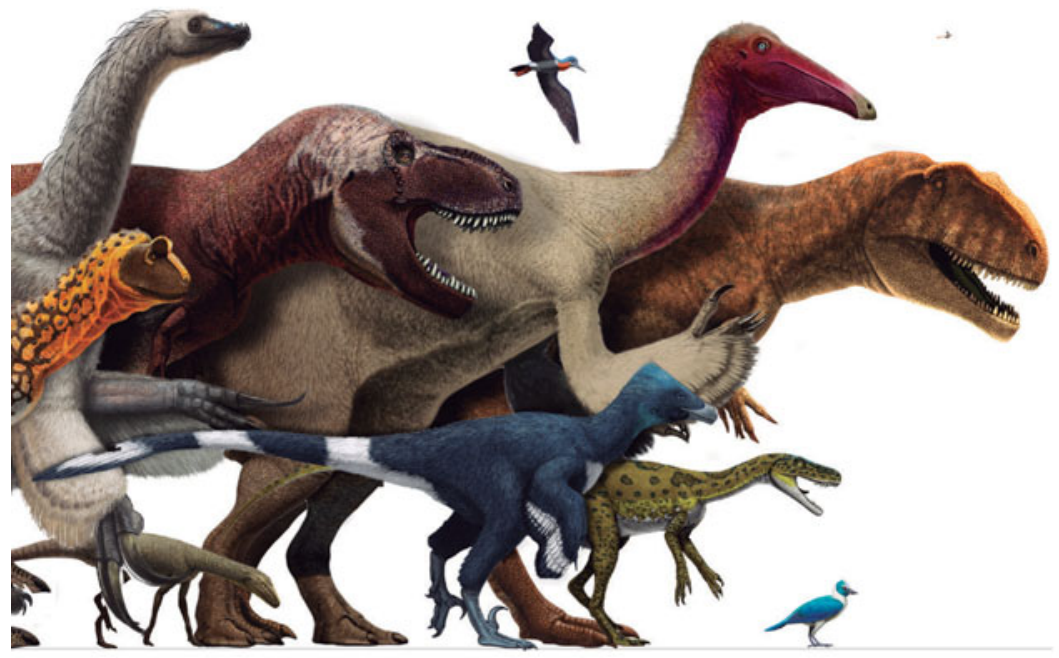

Illustrated by Andrey Atuchin \& Sante Mazzei
An illustrated record book of sauropod facts and figuresthe hugest, the oldest, the most intelligent, and more

- Features a wealth of comparative records

- Includes more than 2,000 diagrams and technical drawings and hundreds of full-color reconstructions

- Covers all known sauropodomorph species

- Provides listings of footprints, biometric specifications, and scholarly and popular references

DPINCETON UNIVERSITY PRESS 